\title{
THE RHETORIC OF POLITICAL EMOTIONS IN THE INTERNET NEWS DISCOURSE
}

\section{Ekaterina V. Teneva}

St Petersburg State University. Saint Petersburg, Russia. Email: ekateneva[at]gmail.com

\begin{abstract}
The paper focuses on the issues of public opinion manipulation and emotionalization of the Internet news discourse. The purpose of this study is to identify the specifics of political emotions and their rhetorical potential in the Internet news discourse. Through the discourse analysis of the statements uttered by politicians and taken from the news stories of the highly circulated British and American online media, political emotions are defined as a particular type of emotions intended to manipulate public opinion both emotionally and politically. The analysis of the rhetorical potential of political emotions reveals that political emotions can be used with the aim of social solidarity, group identification, decision-making, shaping public opinion, discrediting the opponent, polarizing social groups as well as enhancing the public image of a politician in the Internet news discourse. The findings provide the support for the hypothesis that political emotions play an important role in modern argumentation, leaving the facts behind and becoming a key factor that determines the credibility of information in the modern online media. The results of this study can be applied in the field of linguistics, journalism, psychology and political science. A range of implications for understanding the complex nature of emotions and their key role in the Internet news discourse is explored.
\end{abstract}

\section{Keywords}

political emotions; manipulation; emotionalization; Internet news discourse; media studies

This work is licensed under a Creative Commons «Attribution» 4.0 International License 


\title{
РИТОРИКА ПОЛИТИЧЕСКИХ ЭМОЦИЙ В НОВОСТНОМ ИНТЕРНЕТ-ДИСКУРСЕ
}

\author{
Тенева Екатерина Веселиновна \\ Санкт-Петербургский государственный университет. Санкт-Петербург, Россия. \\ Email: ekateneva[at]gmail.com
}

\begin{abstract}
Аннотация
Статья посвящена вопросам манипуляции общественным мнением и эмоционализации новостного Интернет-дискурса. Целью настоящей работы является выявление специфики политических эмоций и их риторического потенциала в новостном Интернет-дискурсе. В результате дискурсивного анализа высказываний, сделанных политиками и взятых из новостных сообщений высокотиражных британских и американских Интернет-СМИ, политические эмоции определяются как особый тип эмоций, используемых с целью как эмоциональной, так и политической манипуляции общественным мнением. Анализ риторического потенциала политических эмоций показывает, что они могут быть использованы в новостном Интернет-дискурсе с целью социальной солидарности, групповой идентификации, принятия решений, формирования общественного мнения, дискредитации оппонента, поляризации социальных групп, а также улучшения имиджа политика. Полученные данные подтверждают гипотезу о том, что политические эмоции играют важную роль в современной аргументации, оставив факты позади и став главным фактором, определяющим достоверность информации в современных Интернет-СМИ. Результаты этого исследования могут быть применены в области лингвистики, журналистики, психологии и политологии. В статье исследуется ряд вопросов, необходимых для понимания сложной природы эмоций и их ключевой роли в новостном Интернет-дискурсе.
\end{abstract}

\section{Ключевые слова}

политические эмоции; манипуляция; эмоционализация; новостной Интернетдискурс; медиаисследования

Это произведение доступно по лицензии Creative Commons «Attribution» («Атрибуция») 4.0 Всемирная 


\section{INTRODUCTION}

It is undeniable that journalists are the first teachers of this society as the news written by them reaches every doorstep. Our society reads it to get informed, become knowledgeable and proactive (Khattri, 2019, p. 120). New era of journalistic work is influenced by the establishment of online journalism (Hudikova, 2020, p. 126). It is also characterized by the rise of new media technologies which are defined as technologies that aid the transfer of information or communications through digital techniques (Adjin-Tettey \& Mbatha, 2020, p. 17). The advent of the Internet and digital technologies has fundamentally changed the way recipients consume media content (Moravcikova, 2020, p. 29). Under the influence of modern technologies new media as a mediator between the government and society have transformed our communication, including online interaction, and become a means of manipulating public opinion as well as a tool for struggle both for power and readers' attention. Thus, in order to understand the complexity of this transformation and its profound effect on society a thorough study of manipulative tools, rhetorical devices and their language markers used for influencing a mass addressee in the new media needs to be carried out.

The present study is of relevance and particular interest since the phenomenon of emotions has a profound effect on the global political, economic and social processes. This is due to several factors:

1) The Internet is an integral part of social communication of a modern person. Online media alongside with social media play an important role in shaping the audience's perception of social, political and cultural events and problems.

2) Modern political processes are rife with examples of the influence of emotions on politics. Currently, almost every political episode or event is covered and accompanied by emotional experiences in the media.

In the post-truth era online media are characterized by the dominance of unverified and fabricated facts, a large number of fake news, conspiracy theories as well as the prevalence of the emotional argumentation over the factual and rational information (Bykov et al., 2019, p. 6). For instance, according to the study of Khattri (2019), about 78\% of journalists in Jaipur adopt information furnished by unreliable and uncertified sources while using social media. Helvoort and Hermans (2020) conclude that the spread of fake news is considered a threat for democracy and civic participation in a lot of European countries.

The term "post-truth" era was coined by Keyes (2004) who argued that deception is becoming more prevalent in the modern media-driven world and is viewed as something acceptable. Campaigns of disinformation using emo- 
tional manipulation and lies (or half-lies) are a common practice of the modern political processes (Bykov et al., 2019). Rational arguments and objective facts no longer play the role of a key to attracting the audience, whereas the appeal to emotions has become ubiquitous, especially in the new media. For this reason, it is vital to study emotions in the Internet news discourse.

\section{METHODS}

This paper represents a case study of the phenomenon of political emotions in the Internet news discourse. The aim of the study is to provide new insights into the understanding of the notion of political emotions and their role in the news coverage of political events. There are several research objectives which facilitate the achievement of the research aim. They are as follows:

a) to identify the specifics of political emotions in the English-language Internet news discourse;

b) to analyze their rhetorical functions in this type of discourse;

c) to detect their linguistic markers and the main rhetorical devices used for emotional manipulation.

The research hypothesis suggests that political emotions have a manipulative character and play one of the key roles in shaping public opinion in the Internet news discourse.

A discourse analysis of more than 100 news stories taken from the online papers published between 2001 and 2020 was used to detect the linguistic markers of political emotions and analyze the implications of the emotive language used by politicians in the news statements. News stories were collected using LexisNexis database as a data collection tool. The British and American papers, including The Times, The Guardian, The Telegraph, The Local, The New York Times and The Washington Post, were selected based on their high quality and popularity in the UK and USA, as they are considered to be the most reputable, influential and credible papers that may contribute to the reliability of the scientific results of the analysis of the collected material.

The content analysis of the news stories was used to make inferences about the specifics of political emotions and their rhetorical functions in the Internet news discourse.

\section{DISCUSSION}

It is worth noting that emotions have always been an essential and integral part of communication process, whether it is everyday speech or political communication. 
In fact, emotions can reflect not only our feelings but also our beliefs, values and even judgments or evaluative thoughts. According to Aristotelian rhetoric, emotions can be cognitive and embody thoughts which can be evaluated like any ideas (Aristotle, as cited in Coelho \& Huppes-Cluysenaer, 2018, p. 14).

Furthermore, emotions can be seen as a tool of public opinion manipulation. By manipulation we mean "a type of psychological impact which is exerted on the addressee by imposing implicit (or hidden) goals, desires, intentions or attitudes towards some event, thing or person that do not coincide with those of the addressee" (Chernyavskaya, 2006, p. 56). In other words, it is a type of impact which forces the addressee to accept the author's viewpoint without any evidence or proofs. From Aristotle's viewpoint, "the orator has to cultivate certain emotions in an audience to instill an attitude oriented toward following the rule of law" (Aristotle, as cited in Coelho \& Huppes-Cluysenaer, 2018, p. 9). In other words, by imposing certain emotions on the audience, a speaker influences the latter and makes it accept the view that is advantageous for him/her. The same conclusion was made by Le Bon, who documented about emotions and argued that "given to exaggeration in its feelings, a crowd is only impressed by excessive sentiments. An orator wishing to move a crowd must make an abusive use of violent affirmations. To exaggerate, to affirm, to resort to repetitions, and never to attempt to prove anything by reasoning are methods of argument well known to speakers at public meetings" (Le Bon, 1995, p. 34-35). Van Dijk (1988) convincingly argues that facts are better described and remembered if they contain strong emotions. From this perspective, in order to convince mass audience the speaker (orator) has to use emotional manipulation rather than logical argumentation.

Regarding the appeal to emotions in the media, it is worth saying that they are considered to be one of the determining factors in defining news value. In general, the impact in the media can be carried out both through the use of logical and emotional methods of influence. The logical way of influencing the audience either does not always work or works not for everyone, since a reader tends to avoid the information that can prove to him/her that his/her behavior or views can be erroneous. Rational argumentation seems to have a reverse effect, forcing the news audience to trust and rely on unverified facts as well as emotional statements in the media. Therefore, the appeal to emotions has become the most effective and quickest way to give a news story more prominence, draw the audience's attention to it and manipulate public opinion.

Currently, the study of emotions in the media has become of particular importance to many scientists (Slaby \& Szanto, 2020). Research reveals that journalists increasingly incorporate emotional elements in news stories (Aich- 
berger \& Huber, 2020). Emotions influence the way the news audience perceives information and forms its opinion (Kuklinski, 2001). The transmission of emotions in the media is almost as important as that of knowledge (Bassols et al., 2013). For instance, there are certain emotions that contribute towards communicative success of TV programs by capturing viewers' attention and not concentrating on their knowledge of the matter. This may be explained by the fact that the audience is diverse and can be unprepared for the scientific or technical issues discussed in these programs. In this regard, emotionalization, which is increasingly dominant in the modern media, becomes an important strategy in the programs that seek to spread scientific knowledge among the general public.

The use of emotionalization strategy has become one of the distinguished features of the modern Internet news discourse. It can be identified as "a deliberate use of emotive language and rhetorical devices in the media" (Teneva, 2019, p. 47). Its aim is to create a positive or negative image (opinion or attitude) of some person (or event) in the media in order to manipulate public opinion. Emotionalization can also be defined as the intentional "evoking of emotions" (Flemming et al., 2018, p. 1).

The issue of emotionalization of the media sphere has always been relevant. Habermas's (1991) position reflects the existing ambivalence towards mass media. On the one hand, he claims that media make it difficult for their audience to form rational-critical opinion which could oppose the established power. From his viewpoint, media provoke emotional responses from their audience, thus distracting it from the political actions and making it reluctant to the decision-making process. Following the views of Habermas, Lunt and Stenner (2005) consider "The Jerry Springer Show" to be an emotional public sphere and conclude that this TV show has little to do with rational-critical discussion.

On the other hand, Habermas considers media to be an ideal platform for public communication that might generate the critical consensus on the prevailing issues of the day (Habermas, as cited in Livingstone \& Lunt, p.10). Thus, the influence of certain emotions that are used in the media cannot be undervalued or neglected as they can be thought-provoking and make substantial contributions to social, economic and political spheres. For instance, Okpadah notes that TV coverage "has affected and influenced the trends of world politics” (Okpadah, 2020, p.160).

In general, emotions have a direct impact on political processes (Brecke \& Long, 2003). Nussbaum mentions that "all societies are full of emotions $<\ldots>$, including anger, fear, disgust, sympathy, envy, guilt, grief, many forms of love. Some of these emotions have little to do with political principles or the public culture, but others are different: they take as their object the nation, the 
nation's goals, its institutions and leaders...” (Nussbaum, 2013, p. 126). In this regard, there is a correlation between political realms and the types of emotions or reactions that they evoke or by which they can be characterized. It is also evident that certain emotions have political implications. For instance, it is of interest for Cvetkovich (2010) why some sentiments are valued in public communication while others are judged irrelevant.

From our viewpoint, political emotions can be defined as a set of conscious and unconscious emotional reactions of subjects or objects of political reality to political events or figures as well as changes in the political environment with the purpose of public opinion manipulation. We tend to assume that the main purpose of the appeal to political emotions in the media is to evoke certain feelings in the addressee in order to identify and convince him/ her in the correctness of the political arguments, which, namely, can be called emotional identification. By identification we mean "a general principle of communication process used to make a speaker's viewpoint acceptable to the addressee and, thereby, convince him/her" (Teneva, 2019, p. 47). Burke (1969) considered identification to be a key principle of rhetoric and claimed that identification was more important than persuasion. In other words, in order to convince the news audience it is necessary to identify with it. From this perspective, identification can be considered one of the fundamental premises of manipulation.

There are several types of identification in the new media. Firstly, journalists as well as politicians can identify with the readers' or voters' opinions by directly addressing them and making them believe that they share the same opinions. Secondly, identification with authority (experts or materials containing statistics) as well as identification with popular opinion that exists in the media have also become a common tool of manipulating public opinion in the modern media. Nevertheless, emotional identification remains the most widely spread in the new media, especially on social media, and is aimed at "emotional infection" of the addressee by identifying the feelings and emotional state of the speaker with the addressee's feelings in order to manipulate $\mathrm{him} /$ her. Therefore, the use of emotional identification which is seen as an essential premise of manipulation has become increasingly widespread both on social media and in the new media.

\section{RESULTS}

Within the framework of this paper political emotions are viewed as one of the common tools of emotionalization strategy used to manipulate the opinions of the readers of online papers. For the purpose of this analysis, we have studied over 100 statements taken from the British and American online 
papers and concluded that political emotions perform several rhetorical functions:

\section{Social solidarity and group identification}

The main function of political emotions is the function of social solidarity or group identification with the audience. For instance, the emotion of hope is used in the Internet news stories with the aim of political integration in order to stimulate positive perception of information by the audience, reduce political tension in conflict situations, influence the addressee as well as convince him/her in the rightness of the politician's opinion. To illustrate it, we need to look at the following examples:

1) "We hope that the new leadership of the United States will be more constructive, and will help us come to a mutually acceptable solution," Putin said in a speech in St. Petersburg (Levy, 2008).

2) "I [Jiang Zemin] hope the Western world can understand China better. This is not simply an issue that has a bearing on myself. It actually has a bearing on the pride and feelings of the 1.2 billion Chinese people and the tens of millions of Chinese descendants overseas. They all hope that Taiwan and the mainland can be reunified at an early date" (Sulzberger, 2001).

In these examples both politicians express hope which is aimed at a positive solution of the problem by identifying their opinion with the opinion of the addressee and the whole country, whose interests they represent in the international political arena.

Example № 1 shows that Russia's President, Vladimir Putin, expresses his hope for a better relationship between Russia and America by identifying his opinion with that of the addressee. For that purpose he uses the inclusive pronoun "we" alongside with the verb denoting hope, which creates the impression of emotional involvement as well as highlights the sense of togetherness of the addressee with the thoughts and feelings of the politician. The feeling of emotional "involvement" and unity with the reader increases the emotionality and persuasiveness of the information, brings the reader closer to the opinion of the politician and is used for his/her "emotional infection".

It should be noted that the pronoun "we" and other inclusive pronouns ("all of us", "we all", "many of us", "most of us", "everyone", "anyone", "no one", etc.) have rhetorical functions: they remove responsibility from the speaker, shifting it to the addressee as well as making the statement sound less categorical so as not to irritate the addressee and avoid political tension. The verb "expect" which is used in the statement is central in the "expectation and 
hope" verb system, denoting anticipation and expectation of a positive answer from the addressee. The use of the emotive language with a positive meaning ("constructive", "a mutually acceptable") also contributes to the emotional impact on the addressee.

In example № 2 the ex-leader of China, Zhang Zemin, expresses his hope for a positive solution to the Taiwan problem, namely, the complete unification of China with Taiwan. The Chinese leader identifies his emotional state with the feelings of the entire Chinese people by addressing them (" 1.2 billion Chinese people and the tens of millions of Chinese descendants overseas”) in order to show that he is one of them.

Thus, the use of emotions with the intention of identification and solidarity has a profound effect on the mass audience, forcing it to trust the words of the politicians. This is one of the widespread manipulative tools in the Internet news discourse.

\section{Motivation in decision-making process}

Emotions in the new media are considered one of the main factors in regulating social behaviour, polarizing social groups as well as shaping decision-making since media are generally regarded as "instruments of socialization" (Polievkova, 2020, p. 64). In this regard, political emotions can be seen as a key to decision-making process. They motivate the audience to take actions that benefits politicians, which is ultimately aimed at emotional manipulation. Let us consider the following examples:

3) "My hope is that newly elected President Trump will use this opportunity much as President Nixon did in going to China," Blumenthal said (Lois, 2016).

4) Trump turned to Zelenskiy and declared: "I really hope you and President Putin get together and can solve your problem” (Higgins, 2019).

In these examples both politicians express their feelings of hope in order to motivate the addressee (their political counterparts) to take actions that are favorable to them and influence the political choices and views of the addressee. The emotional state is actually imposed on the mass audience that is supposed to read these online news stories. The feeling of hope is transmitted on it and undoubtedly increases the persuasiveness of political arguments in its eyes.

Thus, it is assumed that political emotions may be seen as an "argumentation engine" intended to force the audience to make political decisions, which undoubtedly contributes to their significant role in the new media as well as in political communication. 


\section{Shaping public opinion}

Emotions play an essential role in the formation of political judgments or opinions. For instance, a compliment, praise, or approval are often used by politicians in order to form the opinion they need or portray a picture of political reality that is beneficial to them. In these cases, political emotions are often accompanied by identification of the politician's opinion with authority.

In general, the appeal to authority is perceived as an argument which claims to be taken for granted and without any evidence. By referring to authority, a politician actually persuades the audience to accept his/her opinion. Authority in the Internet news discourse is based on the general agreement or consensus of readers' opinions and depends on the popularity, public image and fame of this or that politician rather than on facts or knowledge. Thus, logical arguments are not that important in this type of discourse whereas the emotional and psychological side of the evidence plays a key role. In other words, the main emphasis of the statement is not on the knowledge of the political fact as such, but on its assessment and the degree of its impact on the audience. Here are some examples:

5) "The Conservative MP for Portsmouth North, who has been pictured posing by the pool during a break in training, said that the Prime Minister [David Cameron] would back her appearance on the programme" (Dominicza, 2014).

6) "This isn't about me and it's not about Senator Clinton. As I've said before, she was a friend before this campaign. She'll be a friend after it's over. (Cheers.) I respect her. I respect her as a colleague. I congratulate her on her victories tonight. She's been running an outstanding race" (Obama, 2008).

It is obvious from these examples that facts and personal opinions of the world famous politicians or political institutions are used as arguments to enhance the image of the discussed politicians so that the addressee has no choice but to accept their opinion (if David Cameron or Barack Obama supports the politician). For the purpose of emotional manipulation politicians use emotive language with a positive meaning - the words denoting approval, respect and trust such as "approve" and "friend". This is called a "halo effect" which is very common in online media. It is a psychological effect when the authority of this or that person is automatically projected onto all the people around him/her, making them believe his/her words (Stepanov, 2002, p. 251). This is in reference to one of the unspoken rules of public communication "worship" and idolization of authority. It is needless to say that a person idolizes people of higher social standing (Teneva, 2020). Thus, the reference to au- 
thority in online media is virtually a substitute for the evidence of the author's viewpoint. Let us consider the following example:

7) "Boris Johnson backs Liam Fox to lead World Trade Organisation... Hours before the deadline for member states to put forward potential candidates, government sources confirmed that the prime minister would back Dr Fox" (Jones, 2020).

The reference to authority (Boris Johnson) is used to enhance the public image of another, less known and less popular politician (Liam Fox). The authority, positive image and fame of Boris Johnson is transferred to Liam Fox, making the audience believe that he is trustworthy. This is one of the most common methods of manipulating public opinion both emotionally and politically in the Internet news discourse.

\section{Discrediting political opponents and polarizing social groups}

When it comes to discrediting the opponents, the politicians tend to use negative political emotions in the Internet news discourse. Accusation tactics is common and refers to personal attacks against a public figure intended to discourage people from believing in this figure or supporting him/her. It implies blaming and defaming some political personalities or celebrities, presenting the situation and the opponent in a negative light. This tactics is used to evoke strong emotional reactions and negative feelings towards a person in order to convince the audience in the rightness of a politician and unite voters (readers). For instance:

8) "Barack Obama re-entered the national political debate, assailing his successor as a 'threat to our democracy' and a demagogue practicing the 'politics of fear and resentment"” (Baker, 2018).

The words with a negative meaning such as "demagogue" are used by Obama to create a negative image of his opponent whom he calls "a threat to democracy". Both labeling and criticizing the opponent is aimed at convincing the audience in the correctness of his negative attitude towards Trump and his policy, thus manipulating public opinion.

Undoubtedly, such negative emotions as criticism and accusations contribute to the polarization of political opinions and further political confrontation. Let us consider another example:

9) According to President Putin, the former Soviet dictator Joseph Stalin was like Oliver Cromwell. "Cromwell is just as much of a bloody dictator as was Stalin," Mr Putin said, in an unexpected intervention at the end of his four-hour televised press conference yesterday (Hoyle, 2013). 
Putin appeals to the negative political stereotypes and draws a parallel between Stalin and Cromwell, calling them both "bloody dictators in order to criticize these politicians and enhance Putin's positive self-image which is contrary to these stereotypes.

It is should be mentioned that the perception of political "authorities" is the mainly based on the stereotypes that the audience has. If the audience has profound knowledge or positive background information about a respected and authoritative politician, it is likely to believe him/her. However, if the audience's background knowledge about a politician is either negative or insufficient, then it is unlikely to believe his/her words, which can result in the inefficiency of the political arguments and loss of trust in the politician's words or even in the credibility of the media source on the whole.

Thus, the appeal to political emotions in online media is more efficient if the news audience has relevant background knowledge or positive stereotypes about the discussed person or issue. As Paglinawan notes, "people trust what they know - what is familiar to them" (Paglinawan, 2020, p. 78). As a result, politician's authority, the interpretation of his/her political decisions and the effectiveness of his/her influence on the audience may depend on the emotional experience of the addressee, his/her positive or negative background knowledge about an event or a person mentioned in the media (Sears, 2001).

\section{Enhancing the public image of politicians}

Many politicians use emotions to improve their self-image. A political apology in the Internet news discourse is often used both to change the opinion of the audience in the way which is favourable to this or that politician and to improve his/her image by portraying himself/herself in a positive light rather than to confess or admit his/her guilt. For instance:

10) "I'm here today to again apologize for the personal mistakes I have made and the embarrassment I have caused. I make this apology to my neighbors and constituents, but I make it particularly to my wife Huma. I had hoped to be able to continue the work that the citizens of my district had elected me to do, to fight for the middle class and those struggling to make it" (Weiner, 2011).

11) "I've committed grave mistakes by offering incorrect analysis during the election ... I apologize to the dear Iranian nation because of my incorrect analyses that was the basis for many wrong actions" (Hider, 2009).

In example № 10 the politician confesses his mistakes in front of his family members, namely, in front of his wife, the former assistant of Hillary Clinton, which undoubtedly contributes to the emotional identification of the 
politician with the audience and enhances the emotional impact on it. Moreover, the politician intends to regain the lost trust and seeks to restore his reputation by addressing his voters and audience - "the citizens of my district". The transition from a personal apology (to his wife) to a public one (to his voters) is used to emotionally "infect" the audience with the politician's emotional state, forcing it to feel his emotions, which is one of the common means of emotional manipulation.

In example № 11, by identifying himself with the audience ("dear Iranian nation"), the politician admits his guilt using the words with a negative meaning: "grave mistakes", "incorrect analysis", "wrong actions". There is a shift from the feeling of personal guilt to the collective sense of compassion. This shift contributes to the emotional manipulation. Moreover, emotional identification with the audience reinforces the positive image of a repentant politician. By evoking the feeling of compassion in the eyes of the audience, he emotionally manipulates it.

Another way to impact the audience emotionally and politically as well as improve the public image is to express cynicism. For instance:

12) The President (Trump) claimed: "Winning is easy, losing is never easy. Not for me". < ..>Claiming a conspiracy to keep from declaring him the victor, Trump said: "This is a fraud on the American public. This is an embarrassment to our country. We were getting ready to win this election. Frankly, we did win this election" (Linskey, 2020).

In this statement Trump calls the recent 2020 US presidential election a fraud, identifying his criticism of the election campaign with the entire American nation by using the pronoun "we". Thus, he demonstrates his confidence in the people's unanimity with his opinion about his victory in the elections. Emotional identification is used to improve the self-image of the politician.

The emotion of fear in the Internet news stories is not only an expression of fear itself, but also an expression of a negative attitude of a politician towards a particular situation (personality) as well as criticism or his/her disagreement with the opinion of the majority. It is used to highlight the politician's point of view, enhance his/her public image and impress the audience. For instance:

13) "So my fear is a People's Vote would not be democratic enough," says Killwick (Macbeth, 2008).

14) "Joe Biden is no friend to Britain. Without Trump in the White House, I fear for the future of Brexit", writes Nigel Farage (Farage, 2020). 
In these examples politicians disagree with the popular public opinion on the matters of the legitimacy of the popular vote (№ 13) and the future of Brexit (№ 14). The emotion of fear not only reflects a feeling of uncertainty about the future or upcoming danger but is an expression of criticism and disagreement with popular public opinion. Thus, it can be assumed that political emotions have an ambivalent nature.

\section{CONCLUSION}

As suggested from the analysis of the empirical material, it can be concluded that political emotions perform several rhetorical functions in the Internet news discourse and are used with the aim of social solidarity, group identification, decision-making, shaping public opinion, discrediting the opponent, polarizing social groups as well as enhancing the public image of a politician.

In fact, political emotions are considered to be manipulative, forcing a reader to accept the politicians' opinion. The emotionality of the arguments given by politicians undoubtedly contributes to their positive public image, forcing the readers to accept their opinion without any factual proofs or evidence, which, to some extent, increases the credibility and authority of both the politician, the information provided and online media source on the whole.

Furthermore, the empirical material shows that political emotions can be ambivalent and, therefore, difficult to interpret. In fact, political emotions can have an ambiguous interpretation, reflecting an ambivalent attitude towards political reality. For example, fear can be viewed as an expression of uncertainty, danger, criticism and disagreement with public opinion.

Another distinguished feature of political emotions that is noticeable in the Internet news discourse is the fact that they convey stereotypes that the audience has about authoritative politicians or political events. In this regard, the degree of persuasiveness of political emotions may depend on the emotional experience of the audience.

The spectrum of the linguistic markers of political emotions is wide. From the linguistic point of view, they can be represented explicitly and implicitly in various ways, including emotive words with a positive or negative meaning, inclusive pronouns, emphasizing words and viewpoint adverbs. From the rhetorical point of view, the rhetorical devices of identification, selfpresentation as well as appeals to emotions, authority and stereotypes can be used to manipulate public opinion emotionally and politically.

Our findings that result from the analysis of more than 100 news stories show that the content of news is shifting from an objective and impersonal event-based reporting to a reporting that is more subjective and emotional 
with statements and arguments based not only on knowledge and facts but also on emotional appeal. This inference contributes to the assumption that new media are currently becoming the tool of emotional manipulation of the news audience. It can be explained by the fact that due to the fast pace of modern life and large Internet consumption modern audience or Internet "users" of new media do not have sufficient time or expertise to reflect on the information in the online papers. Readers need to receive information and be impressed quickly, which, as a result, often leads to the fact that they are emotionally (as well as politically and ideologically) manipulated though they often do not recognize it themselves. Therefore, political emotions are considered one of the most efficient tools of public opinion manipulation in the Internet news discourse, which proves our research hypothesis.

From our analysis of the Internet news discourse, it can also be inferred that due to the overall tendency towards covering more sensational news events in the media, news stories containing statements with "negative" political emotions are more likely to be found.

In conclusion, it should be highlighted that emotional manipulation can lead to subjectivity and misconception of the information. Therefore, future studies should further explore the phenomenon of political emotions and their role in the Internet news discourse.

The awareness of emotional manipulation can help us struggle with propaganda and detect manipulation tools as well as develop expertise in the understanding of the complex nature of our emotions and their key role in the process of communication. The results of the study can be applied in the fields of linguistics, journalism, psychology and political science.

\section{References}

Adjin-Tettey, T. D., \& Mbatha, B. T. (2019). Use and Appropriation of New Media Technologies by Teens: "The e-Teen Model" perspective. Galactica Media: fournal of Media Studies, 1(1), 16-42. doi: 10.24411/2658-7734-2019-00 001

Baker, P. (2018, September 7). Obama Lashes Trump in Debut 2018 Speech. President's Response: 'I Fell Asleep.' The New York Times. Retrieved from https://www.nytimes.com/2018/09/07/us/politics/obama-2018-campaign-trump.html

Bassols, M. M., Cros, A., \& Torrent, A. M. (2013). Emotionalization in new television formats of science popularization. Pragmatics. Quarterly Publication of the International Pragmatics Association (IPrA), 23(4), 605-632. doi: 10.1075/prag.23.4.02bas

Burke, K. (1969). A Rhetoric of Motives. Berkeley; Los Angeles; London: University of California Press. 
Bykov, I. A., Lukyanova, G. V., Martyanova, N. A., Podlesskaya, N. S., \& Rubtsova, M. V. (2019). Manageability and the discourse of online communities in the "post-truth" era. St. Petersburg: Elecsis. (In Russian).

Chernyavskaya, V. E. (2006). The discourse of power and the power of discourse: The problems of persuasion. Moscow: Flinta, Nauka. (In Russian).

Coelho, N. M. M. S., \& Huppes-Cluysenaer, L. (2018). Aristotle on Emotions in Law and Politics. Switzerland: Springer.

Cvetkovich, A., Reynolds, A., \& Staiger, J. (2010). Political Emotions. New York: Routledge.

Dijk, T. A. van. (1988). News as Discourse. Hove; London: L. Erlbaum Associates.

Dominicza, P. (2014, January 14). Penny Mordaunt: David Cameron approves of my appearance on Splash! Retrieved from The Telegraph website: https://www.telegraph.co.uk/ news/politics/conservative/10 570302/Penny-Mordaunt-David-Cameron-approvesof-my-appearance-on-Splash.html

Farage, N. (2020, November 11). Joe Biden is no friend of Britain. The Telegraph. Retrieved from https:/www.telegraph.co.uk/news/2020/11/11/joe-biden-no-friend-britain/

Flemming, D., Cress, U., Kimmig, S., Brandt, M., \& Kimmerle, J. (2018). Emotionalization in Science Communication: The Impact of Narratives and Visual Representations on Knowledge Gain and Risk Perception. Frontiers in Communication, 3(3), 1-9. doi: 10.3389/fcomm.2018.00003

Habermas, J. (1991). The Structural Transformation of the Public Sphere: An Inquiry Into a Category of Bourgeois Society. Cambridge, MA: MIT Press.

Helvoort, (Jos) van, \& Hermans, M. (2020). Effectiveness Of Educational Approaches To Elementary School Pupils (11 Or 12 Years Old) To Combat Fake News. Media Literacy and Academic Research, 3(2), 38-47.

Hider, J. (2009). Iran calls for death penalty on reformists in dock. The Times. Retrieved from https://www.thetimes.co.uk/article/iran-calls-for-death-penalty-on-reformists-indock-cg502ldgx $9 \mathrm{z}$

Higgins, A. (2019, December 9). In First Meeting With Putin, Zelensky Plays to a Draw Despite a Bad Hand. The New York Times. Retrieved from https:/www.nytimes.com/ 2019/12/09/world/europe/putin-zelensky-paris-ukraine.html

Hoyle, B. (2013, December 20). Cromwell and Stalin: Just two of a kind, says Putin. Retrieved from https://www.thetimes.co.uk/article/cromwell-and-stalin-just-two-of-a-kindsays-putin-8mfz2pc35qp

Huber, B., \& Aichberger, I. (2020). Emotionalization in the Media Coverage of Honey Bee Colony Losses. Media and Communication, 8(1), 141-150. doi: 10.17645/ mac.v8i1.2498

Hudíková, Z., \& Pravdová, H. (2020). Establishment Of Procedures In The Creation Of Extended Multimedia News Reports. Media Literacy and Academic Research, 3(2), 125140 . 
Jones, O. W., Callum. (2020, July 9). Boris Fohnson backs Liam Fox to lead World Trade Organisation. Retrieved from https://www.thetimes.co.uk/article/boris-johnson-backs-liamfox-to-lead-world-trade-organisation-66chvwq9m

Keyes, R. (2004). The Post-Truth Era: Dishonesty and Deception in Contemporary Life. New York: St. Martin's Publishing Group.

Khattri, N. (2019). Media Literacy, Journalist and Empowerment of Democracy. Galactica Media: Fournal of Media Studies, 1(1), 118-125. doi: 10.24411/2658-7734-2019-00006

Kuklinski, J. H., \& Chong, D. (2001). Citizens and Politics: Perspectives from Political Psychology. New York: Cambridge University Press.

Le Bon, G. (1895). The Sentiments and Morality of Crowds. In: The Crowd: A study of the popular mind (2nd ed.). Dunwoody, Georgia: Norman S. Berg.

Levy, C. J. (2008, October 24). Putin and Medvedev hope for brighter future with Obama. The New York Times. Retrieved from https://www.nytimes.com/2008/11/24/world/europe/24iht-russia.4.18112548.html

Linskey, A., Olorunnipa, T., \& Rucker, P. (2020, November 4). Presidential election hangs in balance as Trump falsely asserts fraud and makes a claim of victory. Washington Post. Retrieved from https://www.washingtonpost.com/politics/presidential-electionhangs-in-the-balance-in-a-country-convulsed-by-crisis/2020/11/04/c2a3ec26-1e1711eb-90dd-abd0f7086a91_story.html

Livingstone, S. M., \& Lunt, P. K. (1994). The mass media, democracy and the public sphere. In Talk on Television: Audience Participation and Public Debate (pp. 9-35). London: Routledge.

Lois, B. (2016, December 15). Democrats' hope for gun control reform: Appeal to Trump's 'unpredictable' nature. Retrieved from The Guardian website: http://www.theguardian.com/us-news/2016/dec/15/gun-control-reforms-trump-richard-blumenthal-sandy-hook

Long, W. J., \& Brecke, P. (2003). War and Reconciliation: Reason and Emotion in Conflict Resolution. Cambridge, MA: MIT Press.

Lunt, P., \& Stenner, P. (2005). The Jerry Springer Show as an emotional public sphere. Media, Culture \& Society, 27(1), 59-81. doi: 10.1177/0 163443705049058

Macbeth, A. (2018, December 7). 'It's better than no deal': Do Brits in Europe hope Theresa May wins Brexit vote? Retrieved from The Local website: https://www.thelocal.com/ 20181 207/should-parliament-in-the-uk-vote-for-or-against-the-brexit-deal-yourviews

Moravčíková, E. (2020). Media Manipulation And Propaganda In The Post-Truth Era. Media Literacy and Academic Research, 3(2), 23-37.

Nussbaum, M. C. (2013). Political Emotions: Why Love Matters for Fustice. Harvard: Harvard University Press.

Obama, B. (2008, February 5). Barack Obama’s Feb. 5 Speech. The New York Times. Retrieved from https://www.nytimes.com/2008/02/05/us/politics/05text-obama.html 
Okpadah, S. O. (2020). The Imperative Of Television In Nigerian Politics. Media Literacy and Academic Research, 3(2), 159-168.

Paglinawan, W. M. C. (2020). University Students Engagement With And Disengagement From Fake News. Media Literacy and Academic Research, 3(2), 77-87.

Polievková, P. (2020). Family Socioeconomic Status And Parents' Education As Indicators Of The Primary Use Of Digital Media By Children. Media Literacy and Academic Research, 3(2), 63-76.

Sears, D. O. (2001). The Role of Affect in Symbolic Politics. In J. H. Kuklinski (Ed.), Citizens and Politics (1st ed., pp. 14-40). Cambridge University Press. doi: 10.1017/ CBO9780511896941003

Slaby, J., \& Szanto, T. (2020). Political emotions. London, New York: Routledge.

Stepanov, A. A. (2002). Ontognoseological concept of authority (Dissertation). Tomsk State University, Tomsk. (In Russian).

Sulzberger, A. Jr. (2001, August 10). CHINA'S LEADERS; In Jiang's Words: 'I Hope the Western World Can Understand China Better'. The New York Times. Retrieved from https://www.nytimes.com/2001/08/10/world/china-s-leaders-jiang-s-words-hopewestern-world-can-understand-china-better.html

Teneva, E. V. (2019). Emotional identification in the political communication (based on the modern British mass media discourse). Colloquium-fournal, 14(38), 47-48. doi: 10.24411/2520-6990-2019-10 426 (In Russian).

Teneva, E. V. (2020). The 'halo effect' in the political discourse of the English-language online media. Russian Linguistic Bulletin, (3), 106-109. doi: 10.18454/RULB.2020.23.3.9

Weiner, A. (2011, June 16). Anthony Weiner Resigns. The New York Times. Retrieved from https:/www.nytimes.com/2011/06/17/opinion/17fri4.html

\section{Список литературы}

Adjin-Tettey, T. D., \& Mbatha, B. T. (2019). Use and Appropriation of New Media Technologies by Teens: "The e-Teen Model" perspective. Galactica Media: fournal of Media Studies, 1(1), 16-42. doi: 10.24411/2658-7734-2019-00 001

Baker, P. (2018, September 7). Obama Lashes Trump in Debut 2018 Speech. President's Response: 'I Fell Asleep.' The New York Times. Retrieved from https://www.nytimes.com/2018/09/07/us/politics/obama-2018-campaign-trump.html

Bassols, M. M., Cros, A., \& Torrent, A. M. (2013). Emotionalization in new television formats of science popularization. Pragmatics. Quarterly Publication of the International Pragmatics Association (IPrA), 23(4), 605-632. doi: 10.1075/prag.23.4.02bas

Burke, K. (1969). A Rhetoric of Motives. Berkeley; Los Angeles; London: University of California Press.

Coelho, N. M. M. S., \& Huppes-Cluysenaer, L. (2018). Aristotle on Emotions in Law and Politics. Switzerland: Springer.

Cvetkovich, A., Reynolds, A., \& Staiger, J. (2010). Political Emotions. New York: Routledge. 
Dijk, T. A. van. (1988). News as Discourse. Hove; London: L. Erlbaum Associates.

Dominicza, P. (2014, January 14). Penny Mordaunt: David Cameron approves of my appearance on Splash! Retrieved from The Telegraph website: https://www.telegraph.co.uk/ news/politics/conservative/10 570302/Penny-Mordaunt-David-Cameron-approvesof-my-appearance-on-Splash.html

Farage, N. (2020, November 11). Joe Biden is no friend of Britain. The Telegraph. Retrieved from https://www.telegraph.co.uk/news/2020/11/11/joe-biden-no-friend-britain/

Flemming, D., Cress, U., Kimmig, S., Brandt, M., \& Kimmerle, J. (2018). Emotionalization in Science Communication: The Impact of Narratives and Visual Representations on Knowledge Gain and Risk Perception. Frontiers in Communication, 3(3), 1-9. doi: 10.3389/fcomm.2018.00003

Habermas, J. (1991). The Structural Transformation of the Public Sphere: An Inquiry Into a Category of Bourgeois Society. Cambridge, MA: MIT Press.

Helvoort, (Jos) van, \& Hermans, M. (2020). Effectiveness Of Educational Approaches To Elementary School Pupils (11 Or 12 Years Old) To Combat Fake News. Media Literacy and Academic Research, 3(2), 38-47.

Hider, J. (2009). Iran calls for death penalty on reformists in dock. The Times. Retrieved from https://www.thetimes.co.uk/article/iran-calls-for-death-penalty-on-reformists-indock-cg502ldgx $9 \mathrm{z}$

Higgins, A. (2019, December 9). In First Meeting With Putin, Zelensky Plays to a Draw Despite a Bad Hand. The New York Times. Retrieved from https://www.nytimes.com/ 2019/12/09/world/europe/putin-zelensky-paris-ukraine.html

Hoyle, B. (2013, December 20). Cromwell and Stalin: Fust two of a kind, says Putin. Retrieved from https://www.thetimes.co.uk/article/cromwell-and-stalin-just-two-of-a-kindsays-putin-8mfz2pc35qp

Huber, B., \& Aichberger, I. (2020). Emotionalization in the Media Coverage of Honey Bee Colony Losses. Media and Communication, 8(1), 141-150. doi: 10.17645/ mac.v8i1.2498

Hudíková, Z., \& Pravdová, H. (2020). Establishment Of Procedures In The Creation Of Extended Multimedia News Reports. Media Literacy and Academic Research, 3(2), 125140 .

Jones, O. W., Callum. (2020, July 9). Boris fohnson backs Liam Fox to lead World Trade Organisation. Retrieved from https:/www.thetimes.co.uk/article/boris-johnson-backs-liamfox-to-lead-world-trade-organisation-66chvwq9m

Keyes, R. (2004). The Post-Truth Era: Dishonesty and Deception in Contemporary Life. New York: St. Martin's Publishing Group.

Khattri, N. (2019). Media Literacy, Journalist and Empowerment of Democracy. Galactica Media: Fournal of Media Studies, 1(1), 118-125. doi: 10.24411/2658-7734-2019-00006

Kuklinski, J. H., \& Chong, D. (2001). Citizens and Politics: Perspectives from Political Psychology. New York: Cambridge University Press. 
Le Bon, G. (1895). The Sentiments and Morality of Crowds. In: The Crowd: A study of the popular mind (2nd ed.). Dunwoody, Georgia: Norman S. Berg.

Levy, C. J. (2008, October 24). Putin and Medvedev hope for brighter future with Obama. The New York Times. Retrieved from https://www.nytimes.com/2008/11/24/world/europe/24iht-russia.4.18112548.html

Linskey, A., Olorunnipa, T., \& Rucker, P. (2020, November 4). Presidential election hangs in balance as Trump falsely asserts fraud and makes a claim of victory. Washington Post. Retrieved from https:/www.washingtonpost.com/politics/presidential-electionhangs-in-the-balance-in-a-country-convulsed-by-crisis/2020/11/04/c2a3ec26-1e1711eb-90dd-abd0f7086a91_story.html

Livingstone, S. M., \& Lunt, P. K. (1994). The mass media, democracy and the public sphere. In Talk on Television: Audience Participation and Public Debate (pp. 9-35). London: Routledge.

Lois, B. (2016, December 15). Democrats' hope for gun control reform: Appeal to Trump's 'unpredictable' nature. Retrieved from The Guardian website: http://www.theguardian.com/us-news/2016/dec/15/gun-control-reforms-trump-richard-blumenthal-sandy-hook

Long, W. J., \& Brecke, P. (2003). War and Reconciliation: Reason and Emotion in Conflict Resolution. Cambridge, MA: MIT Press.

Lunt, P., \& Stenner, P. (2005). The Jerry Springer Show as an emotional public sphere. Media, Culture \& Society, 27(1), 59-81. doi: 10.1177/0 163443705049058

Macbeth, A. (2018, December 7). 'It's better than no deal': Do Brits in Europe hope Theresa May wins Brexit vote? Retrieved from The Local website: https:/www.thelocal.com/ 20181 207/should-parliament-in-the-uk-vote-for-or-against-the-brexit-deal-yourviews

Moravčíková, E. (2020). Media Manipulation And Propaganda In The Post-Truth Era. Media Literacy and Academic Research, 3(2), 23-37.

Nussbaum, M. C. (2013). Political Emotions: Why Love Matters for fustice. Harvard: Harvard University Press.

Obama, B. (2008, February 5). Barack Obama’s Feb. 5 Speech. The New York Times. Retrieved from https://www.nytimes.com/2008/02/05/us/politics/05text-obama.html

Okpadah, S. O. (2020). The Imperative Of Television In Nigerian Politics. Media Literacy and Academic Research, 3(2), 159-168.

Paglinawan, W. M. C. (2020). University Students Engagement With And Disengagement From Fake News. Media Literacy and Academic Research, 3(2), 77-87.

Polievková, P. (2020). Family Socioeconomic Status And Parents' Education As Indicators Of The Primary Use Of Digital Media By Children. Media Literacy and Academic Research, 3(2), 63-76.

Sears, D. O. (2001). The Role of Affect in Symbolic Politics. In J. H. Kuklinski (Ed.), Citizens and Politics (1st ed., pp. 14-40). Cambridge University Press. doi: 10.1017/ CBO9780511896941.003 
Slaby, J., \& Szanto, T. (2020). Political emotions. London, New York: Routledge.

Sulzberger, A. Jr. (2001, August 10). CHINA'S LEADERS; In Jiang's Words: 'I Hope the Western World Can Understand China Better'. The New York Times. Retrieved from https://www.nytimes.com/2001/08/10/world/china-s-leaders-jiang-s-words-hopewestern-world-can-understand-china-better.html

Teneva, E. V. (2020). The 'halo effect' in the political discourse of the English-language online media. Russian Linguistic Bulletin, (3), 106-109. doi: 10.18454/RULB.2020.23.3.9

Weiner, A. (2011, June 16). Anthony Weiner Resigns. The New York Times. Retrieved from https:/www.nytimes.com/2011/06/17/opinion/17fri4.html

Быков, И. А., Лукьянова, Г. В., Мартьянова, Н. А., Подлесская, Н. С., \& Рубцова, М. В. (2019). Управляемость и дискурс виртуальных сообществ в условиях политики nостправды. Санкт-Петербург: ЭлекСис.

Степанов, А. А. (2002). Онтогносеологическая концепция авторитета (Dissertation). Томский государственный университет, Томск.

Тенева, Е. В. (2019). Эмоциональная идентификация в политической коммуникации (на примере дискурса современных британских СМИ). Colloquium-fournal, 14(38), 47-48. doi: 10.24411/2520-6990-2019-10426

Чернявская, В. Е. (2006). Дискурс власти и власть дискурса: Проблемы речевого воздействия. Москва: Флинта, Наука. 